\title{
Resources in Economic Geography: From Substantive Concepts Towards a Relational Perspective
}

\author{
Harald Bathelt \& Johannes Glückler
}

\begin{abstract}
Version Post-print/accepted manuscript
Citation Bathelt, H., \& Gluckler, J. (2005). Resources in economic geography:

(published version) From substantive concepts towards a relational perspective. Environment and Planning A, 37(9), 1545-1563.

Copyright / License

Publisher's Statement The version of record [Bathelt, H., \& Gluckler, J. (2005). Resources in economic geography: From substantive concepts towards a relational perspective. Environment and Planning A, 37(9), 1545-1563.] is available online at:

http://epn.sagepub.com/content/37/9/1545

[doi: 10.1068/a37109]
\end{abstract}

How to cite TSpace items

Always cite the published version, so the author(s) will receive recognition through services that track citation counts, e.g. Scopus. If you need to cite the page number of the TSpace version (original manuscript or accepted manuscript) because you cannot access the published version, then cite the TSpace version in addition to the published version using the permanent URI (handle) found on the record page. 
August 26, 2004

Word count: ca. 11.350 (incl. footnotes)

\title{
Resources in Economic Geography: From Substantive Concepts Towards a Relational Perspective
}

\author{
Harald Bathelt \\ Faculty of Geography, Philipps-University of Marburg, \\ Deutschhausstraße 10, D-35032 Marburg, Germany, \\ E-mail: bathelt@staff.uni-marburg.de, \\ URL: http://www.harald-bathelt.de \\ and \\ Johannes Glückler \\ Institute of Economic and Social Geography, \\ Johann Wolfgang Goethe-University of Frankfurt/Main, \\ Postfach 111932, Dantestraße 9, D-60054 Frankfurt/Main, Germany, \\ E-mail: glueckler@em.uni-frankfurt.de, \\ URL: http://www.rz.uni-frankfurt.de/ glueckle
}

Paper submitted to

Environment and Planning A 


\title{
Resources in Economic Geography: From Substantive Concepts Towards a Relational Perspective
}

\begin{abstract}
Resources are crucial for the technological and economic development of firms in spatial perspective. In this paper, we contrast two ways of conceptualizing resources and argue that a conventional, substantive understanding implies a number of shortcomings which can be overcome through the application of a relational conception of resources. In examining four types of resources, i.e. material resources, knowledge, power and social capital, our argument is that resources are constituted in a relational way in two aspects. First, resources are relational in that their generation, interpretation and use are contingent. This depends on the particular institutional structures and social relations, as well as the knowledge contexts and mental models of the agents involved. Second, some types of resources, such as power and social capital, are also relational because they cannot be possessed or controlled by individual agents. They are being built and mobilized through dayto-day social practices. Individuals or groups of agents may appropriate the returns, but not the resources themselves. We conclude that a relational concept reflects the contextual and interactive nature of the selection, use and formation of resources. This offers new insights into the explanation of heterogeneity in firm strategies and trajectories, as well as regional differences in the development of localized industry configurations, such as clusters.
\end{abstract}

Keywords: Relational economic geography, substantive concepts, relational concepts, resources, knowledge, power, social capital

JEL Classifications: B41, B52, D83, L22, O18, O31, Z13 


\section{Introduction}

Firms produce outputs by procuring and transforming inputs, yielding value added. In conventional economic analysis, three types of inputs or production factors are distinguished, i.e. land, labor and capital. Recent economic structures and practices in the reflexive economy (Storper 1997) clearly demonstrate, however, that the existing heterogeneity of strategies and technological developments, taken by firms in varying spatial contexts, cannot be explained by differences in the composition and use of production factors alone. Strategic differentiation, innovation, organization and the economic success of firms are strongly influenced by other factors which can also be conceptualized as resources to be used in the production process. Aside from machinery, equipment and financial capital, other forms of capital -- such as experience, knowledge, social capital and power -- exist and enter production. These resources create an additional challenge in the production process as they are not purely technical in nature and require much more than technological expertise. They are socially constructed entities which rely on collective processes of resource generation and application. This shift has fundamental consequences for the exploitation and use of resources, as well as for our understanding of how they operate.

In this paper, the analysis of resources is shaped by a relational approach to economic geography, which focuses on the analysis of economic interaction in spatial perspective (Bathelt and Glückler 2003a; 2003b; Clark and Tracey 2004). Economic action is viewed as social action which is contextual in that it is always related towards other actors and shared institutional environments. The focus of attention here is directed towards economic and social relations, processes of organizing, problem-solving and innovation, as well as the creation of informal and formal institutions (see, also, Yeung 1998; 2002; Ettlinger 2003; Murphy 2003; Massey 2004). ${ }^{1}$ The main argument of this paper is that a relational conception is more appropriate than a substantive conception to understand the generation and application of resources, as well as to represent the variety and heterogeneity of different uses

\footnotetext{
${ }^{1}$ Social theory has increasingly tended towards a non-essentialist conceptualization of social and economic practice. A relational approach to economic geography is related to various complementary streams of thought from economics, sociology and geography. Most importantly, relational economic geography draws on the embeddedness and network literature (e.g. Granovetter 1985; 1992), on institutional economics (e.g. Nelson and Winter 1982; Hodgson 1998) and the new economic geography (e.g. Storper 1997). Further important examples of non-essentialist perspectives can be found in contributions, such as those on the cultural turn (e.g. Thrift 2000; Lee 2002) or the institutional turn in geography (Amin 1999; 2002).
} 
and values assigned to resources in the reflexive economy. This relational perspective is not limited to analyses at the micro-level. Instead, it aims to combine and integrate micro- and macro-theoretical considerations through the concept of institutions. ${ }^{2}$ On the one hand, institutions shape economic practices and thus should be studied at the level of the economic actor (Hodgson 1998). On the other hand, this institutional context pre-structures economic interaction to some extent, motivates ongoing relationships between agents and enables these to be reproduced. The economic agents we focus on in this paper are individuals and collectives of individuals in firms which interact in local and global production environments. In spatial perspective, we apply our arguments to geographical clusters and other localized production configurations, as well as international production networks.

In the remainder of the paper, we aim to explore different conceptualizations of resources and emphasize the difficulties involved in treating collectively constituted resources in substantive terms. The main section introduces four types of resources, i.e. material resources, knowledge, power and social capital, and discusses the consequences of a substantive versus relational understanding for each resource type. It will be shown that a substantive understanding of resources is inadequate in a number of ways and that these shortcomings can be overcome with a relational conceptualization. The final section summarizes our arguments and demonstrates the potentialities of applying a relational concept in spatial perspective, using the geography of the firm as a reference point.

\section{From a Substantive Towards a Relational Understanding of Resources}

Human action is relational in character because individuals do not act atomistically without context (Granovetter 1985). Economic decisions and their consequences are always shaped by the structure of social relations to other actors and shared institutional conditions. This applies to the selection of goals, the identification of opportunities for particular action, the reference frame for the interpretation of alternative actions, as well as to the course of action itself. In the following subsections, we will apply this view to the analysis of resources

\footnotetext{
2 The conceptual foundations of relational action are in fact based on an institutional perspective (Amin 1999). An important result of this perspective is that the goals and preferences of human action are not predetermined through the assumption of rational, utility-maximizing individuals. "Human agency is neither uncaused nor generally predictable ...”, as Hodgson (2003: 171) puts it. Further, different layers of institutions can exist within a society which support or work against each other. Storper (2003), for instance, argues that the relation between 'community'- and 'society'-level institutions is decisive in understanding why some places grow faster than others.
} 
and suggest to shift our resource conception from a substantive towards a relational understanding. This will be done by systematically pointing out the limitations of the conventional substantive view. We argue that resources are used and/or produced in a relational manner, i.e. in context-specific social processes. This leads to resource heterogeneity which then becomes the basis of competitiveness and economic success. It will be shown that the generation and use of resources relies on interactive learning and decisionmaking, that it is shaped by shared interpretative schemes and that it can easily change, depending on the context. Through this, the ultimate use and value of resources is contingent. Moreover, we demonstrate that relational resources cannot always be appropriated by individual actors. In what follows, we explore four types of resources which are increasingly important in the technology- and knowledge-intensive economy, i.e. material resources, knowledge, power and social capital. The goal of our argument is to illustrate the relational character of each of these resource types (table 1) and emphasize the consequences of this understanding in spatial perspective.

\section{[INSERT TABLE 1 SOMEWHERE HERE]}

\subsection{Material Resources}

When we talk about material resources, we usually think of raw materials, intermediate products, machinery and equipment, as well as different kinds of infrastructure which are used by firms. These resources are limited in terms of their availability and are used up through consumption. ${ }^{3}$ Therefore, a shortage problem exists which drives economic action according to neoclassical economics (Peteraf 1993). From a substantive view, these resources are production factors which can be acquired by firms and which are exploited according to their needs. In a relational understanding, material resources are not automatically viewed as factors with an inherent use-value and pre-determined application. This view acknowledges that resources can be used in many different ways for different purposes. The use-value of a resource depends upon the social context within which goals and capabilities are shaped. Resources can be defined as bundles of possible services, as expressed by Penrose (1959). A

${ }^{3}$ In this respect, there is a remarkable difference between material resources and the other resource types discussed. Knowledge, power and social capital do not diminish when they are used. In contrast, their application can further strengthen and extend them, as new knowledge, power or social capital is generated. 
differentiation between resources and their respective services is necessary because it is possible to acquire and characterize resources independent from the purpose they serve. Only the particular use determines the way in which they enter the production process as inputs, how valuable they are and in which way they might strengthen a firm's competitiveness. Penrose (1997: 31) prefers the term resource over production factor, as the latter does not allow for a distinction between the factor itself and its possible services: "Strictly speaking it is never resources themselves that are 'inputs' in the production process, but only the services that the resources can render."

A relational concept of resources has consequences for our conceptualization of firms. In conventional economic analysis, firms are defined in terms of the outputs they produce. A resource-based view of the firm, in contrast, defines a firm according to its inputs. In this view, firms are defined as bundles of resources and can be characterized by their specific resource profile (Mahoney and Pandian 1992). From this understanding, we can analyze how different combinations of resources shape a firm's economic success (Wernerfelt 1984). Only by distinguishing between material resources and their multiple potential applications is it possible to understand the heterogeneity of firms, output specificity and deviating strategies.

Resources are not only bundles of potential services but also assets for future returns. Firms do not necessarily gain higher returns because they have better resources than others. Their better performance is also a consequence of using their resources in a different or superior manner (Maskell 2001a). The difference in return between the best and second best service of a particular resource can be defined as its quasi-rent (Mahoney and Pandian 1992). Here, the distinction between a substantive and relational understanding of resources becomes quite clear. While the former concept defines resources as objective production factors characterized by pre-defined input-output relationships, the latter emphasizes the multiplicity of potential services of these resources. The particular use of a resource does not only depend on its physical characteristics but is influenced by a number of contextual conditions, some of which are described as below:

(1) Firm-specific competencies. Each firm has a stock of knowledge, capabilities and experience which has developed over time and which shapes the identification of particular uses for the resources at hand. It is through these specific competencies that firms are able to integrate resources into the production process in a certain way. The set of accumulated knowledge of a firm can also be viewed as a resource.

(2) Mental model. The competencies of a firm are part of its overall mental model or dominant logic (Prahalad and Bettis 1986). This interpretative framework impacts the way 
existing competencies are used and enables a joint understanding of knowledge pools. The interpretations which are attached to the internal and external information flows of a firm indicate its organizational capabilities. Routines which have formed over time and through which new information can be processed and transformed into action shape the interpretations. According to Nelson and Winter (1982), organizational routines are the skills of a firm. Through the development and diffusion of new interpretative schemes, it is possible to reinterpret existing knowledge and attach it to new uses, or find new innovative services for existing resources.

(3) Market conditions. The potential returns of an innovative use of resources also depend on the productive opportunities and constraints in the market (Penrose 1959). These productive opportunities define which specific competencies can be combined with or adjusted to one another to be successful. This depends on the overall competitive, demand and supplier-customer environments, capable of supplying innovative resource applications and processing the resources further. However, external market conditions may also constrain the development and use of resources. This depends, for instance, on the market power of key players or institutional constraints such as dominant technological standards.

The above considerations clearly demonstrate that a firm's products, strategies, interactive capabilities and technological trajectories can neither be explained by nor be reduced to the mix of material resources used. On the contrary, the productive and innovative use of resources depends upon the combination of adequate resources, the competencies of a firm, its mental model, existing market conditions and the respective socio-institutional context.

\subsection{Knowledge}

The distinction between resources and their possible services emphasizes that the value and use of material resources are not pre-determined but contingent and depend on their particular social context. Therefore substantive concepts of resources cannot explain how firms gain competitiveness and become innovative. To fully understand this, we have to consider the processes of knowledge generation internal and external to the firm (Maskell 2001a). Interdependencies between the knowledge basis and the structure and strategy of a firm generate a reflexive process of specialization through which particular capabilities are continuously reproduced and extended. At the same time, knowledge is not just the result of the former productive use of resources. It can be conceptualized as a relational resource itself. 
In the knowledge-creation view of the firm (Nonaka, Toyama and Nagata 2000), which can be viewed as a generalization of the resource-based view, knowledge is the decisive asset of a firm while knowledge creation is the key mechanism through which firms produce and sustain competitiveness. In this perspective, knowledge is viewed as the key resource of the developing reflexive or learning economy (Lundvall and Johnson 1994; Boekema, Morgan, Bakkers and Rutten 2000; Strambach 2004). Recent studies have also shown that an adequate explanation and exploration of localized industry networks and clusters requires a knowledgebased view (Maskell 2001b; Malmberg and Maskell 2002; Bathelt 2002) and cannot be limited to the material linkages between firms and resource locations alone. Knowledge is neither a resource which guarantees economic success, much like the effect of an independent variable in a mathematical model, nor does it have inherent, pre-determined consequences as a production input. ${ }^{4}$ Often we can identify situations which are characterized by excess availability of knowledge rather than shortage. The solution to a problem has to combine the different sorts of knowledge at hand (Lundvall and Johnson 1994). To be able to do this, it is necessary to identify the relevant knowledge (know-what) and capable partners (know-who) for the particular context of finding a solution (know-why) and to know how to combine and use this knowledge (know-how). This clearly demonstrates the relational character of knowledge. It is socially constructed and can even become irrelevant outside a particular context of interaction. The latter is the case if other actors are not capable of understanding this knowledge. As opposed to material resources, the stock of knowledge can be extended through intensive usage (Maskell 2001a). ${ }^{5}$ Knowledge differs from material resources and products particularly in two aspects.

\footnotetext{
${ }^{4}$ This is, however, implied in studies which are based on a substantive concept of knowledge, such as many of the new endogenous growth theory (see, for an overview, Maier and Tödtling 1996; Martin and Sunley 1998; Koschatzky 2001).

5 The notion of knowledge as 'stock' appears problematic when using a relational conceptualization. The latter implies that the use and value of knowledge -- as well as that of other resources -- are fundamentally open and constantly changing. It could thus be argued that we should give up images of stocks altogether. We basically do this and use the term 'stock' only as a temporary reference point to describe the amount and value of accumulated resources at a specific point in time in a particular context. As will be demonstrated in the following sections, it is virtually impossible to apply substantive notions of resources in the cases of power and social capital. Here, the notion of 'stock' is quite misleading, as power and social capital refer to network configurations and social relations.
} 
(1) Price determination. Knowledge cannot be treated like an ordinary commodity which can be exchanged through market transactions. Knowledge is hard to trade because it is difficult to specify the exact demand for and supply of it. Even in the case of explicit, codified knowledge it is an arduous task to determine a market price. For a potential buyer to determine the value of a particular set of codified knowledge $s /$ he must know its contents. Similar to Arrow's (1962) point regarding information, one could argue that once the potential buyer knows the contents s/he has acquired it already, thus negating the need to buy it. Further, the evaluation of new explicit knowledge is associated with two difficulties. On the one hand, sufficient tacit knowledge is necessary to be able to interpret and integrate the new knowledge in a useful way (Maskell and Malmberg 1999). On the other hand, an actor needs to possess enough experience-based, non-codified knowledge in order to recognize the potential of new knowledge. Both aspects show that a differentiation between explicit and implicit knowledge is hardly possible as the two are usually combined (Johnson, Lorenz and Lundvall 2002).

(2) Transfer of knowledge. Another problem is associated with the spatial transfer of knowledge. Knowledge which is tacit in nature is embodied in people, machines and other technical systems and thus difficult to transfer (M. Polanyi 1967). Experienced workers know, for instance, exactly how to adjust the production process in a firm to produce maximum quality. It is not easy to transfer this knowledge to third parties. This knowledge is localized in that it is restricted to those actors, firms and places where it exists and is used (Maskell and Malmberg 1999; Bathelt and Glückler 2003a). Amin and Cohendet (2004: 102) emphasize, however, that " $[\mathrm{t}]$ he 'stickiness' of knowledge in these sites ... stems from the unique interactions and combinations of bodies, minds, speech, technologies, and objects that can be found there ... It has little to do with 'native' practices or locally confined assets." In addition, explicit knowledge which is codified can also be quite 'sticky'. This is especially the case when codified knowledge is adjusted to the conditions in a specific context. Contextualized or embedded knowledge which is enriched by localized knowledge is, in turn, less prone to ubiquitification (Maskell and Malmberg 1999). Therefore, tacit and even contextualized codified knowledge generate a competitive advantage to those regional actors who share this knowledge (Asheim 1999; Belussi and Pilotti 2001; Gertler 2003).

The above arguments demonstrate that the use of knowledge is contextual and pathdependent, yet it is also contingent. Already in the process of transforming data and information into knowledge, interpretation occurs through which this information is evaluated with respect to a specific context. To which degree this knowledge is important for a firm not 
only depends upon the technology and market context of that firm, its strategies and absorptive capacity of new knowledge (Cohen and Levinthal 1990; Malecki 2000; Bathelt, Malmberg and Maskell 2004). It is also dependent on the previous experiences this firm had in integrating new knowledge and whether the actors inside the firm are able to recognize the potential of this knowledge in extending their overall competencies. New knowledge originating from different industries or technology fields has no pre-determined best way of applying it but can be used and evaluated in different ways. With respect to existing practices, it can cause incremental, discontinuous or even no changes at all.

The creation of knowledge is a spatially sensitive process which requires a spatial perspective of analysis. Due to the fact that different flows of economic and social interaction overlap spatially and involve different people in various functions (while excluding others who interact in different places), processes of generating knowledge differ from place to place (Bathelt and Glückler 2003b). ${ }^{6}$ New knowledge does not just appear out of nowhere. It is based on existing knowledge and created through a process in which different kinds of knowledge are integrated, transformed and reinterpreted in a meaningful way (Nonaka, Toyama and Nagata 2000). The process of knowledge creation can also be understood as one of knowledge transformation (Nonaka and Takeuchi 1995). This involves that different sources of tacit knowledge are explicated, recombined, internalized into the technical systems and employees' routines and further transformed through processes of learning and socializing. ${ }^{7}$ Through this, production can be organized with fewer costs over time (Lawson and Lorenz 1999). With respect to our analysis of the role of resources, the process of knowledge creation has two particular consequences in spatial perspective.

(1) Spatiality of knowledge transfer. This process clearly shows why knowledge has become so important as a resource in economic life. Organizational deficits and miscommunication at some stage can interrupt the transformation and recombination of

\footnotetext{
${ }^{6}$ Taking this further, a relational reading of place (Amin 2004) implies that local knowledge is never just produced locally based on close-by resources but depends on and is shaped by systematic linkages with other parts of the world through media reports, international business travel, transnational communities and so on. From this, Amin (2004) and Massey (2004) argue for a new relational, non-territorial politics of place which, as a utopia, is not restricted to a limited number of seemingly 'local' issues and actively involves 'external' actors which are connected to a place based on shared stakes and responsibilities.
}

${ }^{7}$ Although it has been recognized that the articulation of tacit knowledge is quite important to enable learning (Tracey, Clark and Lawton-Smith 2002), there is no linear sequence of transforming implicit into explicit knowledge, as could be implied from Bengtsson and Söderholm (2002). 
existing knowledge pools which can result in a lack of innovation and loss of competitiveness. When considering the potential problems which could occur at a single site within a firm, it is easy to imagine how much greater the barriers and risks for miscommunication are in an interfirm innovation context involving actors from different countries and regions (Gertler 1997; 2001). Such innovation processes are quite important, however, to prevent firms from missing out on technological and strategic developments in other regions and nation-states. If firms focus too exclusively on regional networks and neglect market and technology trends elsewhere, a lock-in situation could result (Grabher 1993a; Hellmer, Friese, Kollros and Krumbein 1999; Clark and Tracey 2004). This could undermine the reproduction of a firm's knowledge basis (Bathelt 2002). In an international innovation context, however, the agents involved speak different languages and act according to different norms, rules and other institutional practices. They are not automatically capable of exchanging all details of new knowledge between one another or participating in each other's local buzz of everyday information flow (Grabher 2002; Bathelt, Malmberg and Maskell 2004; Storper and Venables 2004). In order to benefit from long-term learning and knowledge transfers, it is necessary to develop a common institutional basis which enables processes of interactive knowledge generation in trans-local, interregional and supranational contexts (Storper 1997; Depner and Bathelt 2003). This can be accomplished through the development of a multinational or transnational firm structure (Dicken, Forsgren and Malmberg 1994; Dicken 2003), enabling firms to integrate different socio-institutional and cultural frameworks into their competence profile and offer products in one market region which are based on the experiences gathered in other regions.

(2) Spatiality of knowledge creation. The process of knowledge generation further demonstrates that new knowledge is socially constructed in a timely manner (Amin and Cohendet 2004). This process involves various stages which require different organizational structures to be executed efficiently (Nonaka, Toyama and Nagata 2000). The process of articulating various types of tacit knowledge and recombining this knowledge into a new product conception might, for instance, be best organized in a project team of experts who get together for a limited time period to achieve a clearly defined goal (Grabher 2002). In contrast, the process of learning and perfecting production routines can be better performed in a more permanent organizational context such as a workplace within a firm. This also enables the formation of small, flexible teams which are able to conduct short-term problem solving. Nonaka, Toyama and Nagata (2000) use the Japanese concept of 'ba' to refer to the organizational contexts within which individuals interact at a specific time and particular 
(joint or distributed) place(s) over a certain time period (Lee 2001; Kostiainen 2002; Amin and Cohendet 2004). These contexts are fluid and, due to reflexive social practices, change constantly. The existence of 'ba' allows information to be interpreted in a meaningful way and eventually results in new knowledge. Although 'ba' is a social concept, its empirical manifestations are associated with distinct spatialities. It can be the place where technicians in a firm get together to analyze machinery failure or the internet interface through which engineers regularly exchange ideas about new product designs. In this sense, firms can be understood as dynamic configurations of 'ba', although these principles are not restricted to intra-firm organizational contexts.

\subsection{Power}

Substantive concepts view power as the characteristic of an economic actor or organization based on ownership and control of material resources. According to this perspective, agents have power or they have not. By controlling access to these resources, some actors in economic processes dominate others. As a consequence of this understanding, critical analysts have described multinational firms as being extremely powerful, primarily because of their size and capability to regulate access to resources and labor in international markets. This is sometimes recognized as the main cause of stagnation and underdevelopment in third world countries and, therefore, has to be fought against and limited by state intervention. This line of argument still exists today in discussions about the power of firms versus nation-states (e.g. Dicken 2003). Although there is a lot of truth in this, it is based on a limited conceptualization of power. Power cannot be viewed as an 'inscribed capacity' which an actor possesses based on ownership of resources (Allen 1997; 2004). Using a geographical lens, we can find many examples which demonstrate that asymmetrical distributions of material resources do not determine the outcome of economic action. It can, for instance, be quite difficult for a firm to coordinate its production activities in remote branch plants located in different countries even if resource access is under full control of the headquarter. There are also many reports of international mergers and acquisitions which fail because it is not possible to synchronize the activities in the different workplaces despite centralized resource control. $^{8}$

\footnotetext{
${ }^{8}$ This is not to say that there is a simple binary geography of power, as either being centered in a
} localized industry context, such as a cluster from where it radiates, or being placeless and omnipresent in the global circuits of everyday practices (Allen 2004). In a relational view, power works through different levels of 
A relational concept of power drawing from actor-network theory (Latour 1986; Thrift 1996; Jöns 2003) is based on a reflexive understanding which views power as a cause but, at the same time, also as a result of human action (Scott 2001; Allen 2004). The consequences of power are not determined by ownership. Rather, its impact on economic structures and processes cannot be forecasted. If we take interfirm relations in networks or clusters as an example, these are shaped by existing power asymmetries which cause patterns of dominance and dependence and affect the actors' abilities to react to changing markets and institutional structures (Grabher 1993b; Taylor 2000; Bathelt and Taylor 2002). It is, however, problematic to view power asymmetries as being only negative. Under real world conditions, it is hard to identify a network of firms characterized by symmetrical power relations. In fact, such a distribution of power could provide a barrier for problem solving and lead to a situation where conflicting views cause long debates without decisions being made. In contrast, the existence of power asymmetries generates potentials for efficient problem solving and flexible adjustments in production to meet external market changes (Taylor 1995; Lowey 1999; Bathelt 2002). Power asymmetries create some sort of hierarchy and dominance within a network which help to settle conflicts between actors and speed up decision-making processes. This can be quite beneficial but may also create problems. If the agents have too much trust in a given hierarchy, and develop blind confidence in the decisions of dominant firms (Granovetter 1985; Kern 1996), the potential grows for being locked into an inefficient technological trajectory.

If resource control is not sufficient to generate power, we might ask which mechanisms support consistent behavior within a localized industry configuration, allowing the participating firms to act coherently and grow collectively. In the case of a cluster, for instance, we would argue that this industry configuration can only then be considered as such if the internal actors, as well as those external to the cluster, recognize the cluster as an entity which is sufficiently different from its environment and act accordingly. In this view, clusters have causal power because network relations have an 'emergent effect' (Yeung 1994; Dicken, Kelly, Olds and Yeung 2001); that is, they make the cluster visible to others. This implies that the overall effects of network relations within the cluster are greater than those due to the individual powers of its actors. This is the sort of power referred to by Latour (1986) as the ‘powers of association' or as 'power as relationships' (Allen 1997; Taylor 2000). In actor-

social relations which allow for multiple spatialities. "In short, there are no fixed distances, well-defined proximities or ubiquitous forms of rule...” (Allen 2004: 25). 
network theory, those actors who are viewed as having power are able to build networks and develop them further by enrolling other actors (e.g. Murdoch 1995; Smith 2003). Therefore, power is -- similar to social capital -- embedded in all network relations and, at the same time, created through them. ${ }^{9}$

In a regional industry context, such as a cluster, social relations are constantly being produced and reproduced through ongoing communication between the actors, similar ways of solving problems, joint decisions about which technologies to use and the like. This is not a simple diffusion of information from one end to the other. Rather, this should be viewed as a translation process where messages are being transferred to other actors through social relations who then evaluate the information according to their goals. During this transfer, the messages are constantly being reinterpreted, giving each actor the opportunity to change the contents (Latour 1986). Within such a structure of social relations, the role of building networks is not necessarily limited to one or few actors but can change over time.

Of course, it is difficult to establish coherence within a cluster through social relations alone. Material and non-material resources, such as non-human artifacts (e.g. particular technologies, symbols), tools (e.g. manuals, reports) and accepted rules, enable human actors to engage in social relations and keep them going (Murdoch 1995; Dicken, Kelly, Olds and Yeung 2001). The importance of these resources in stabilizing social relations reflects the power of technologies in the sense of Foucault (Allen 1997) or the facilitative power circuit of Clegg (Taylor 2000). Material and non-material resources are the glue of social relations (Latour 1986). ${ }^{10}$ In a cluster context, for instance, particular process and communication technologies serve to stabilize interactions between the actors and firms, as they share the

\footnotetext{
${ }^{9}$ Based on these considerations, Cowling and Sugden (1998) suggest a different, relational understanding of firms which goes beyond an ownership-based classification. They propose to define firms according to their existing network of power relations as a nexus of strategic decision-making structures originating from their centers (Cowling and Sugden 1998: 67). As a consequence, long-term supplier contracts are viewed as internal instead of interfirm transactions. In a similar way, Leborgne and Lipietz (1988) use the term quasi-integration in the case of hierarchical supplier networks. Although this understanding of firms appears attractive we do not apply it in this paper as we are aware of the problems of its operationalization. Due to the high fluidity of power relations, this definition would not form a stable basis for an empirical study of firms.
}

${ }^{10}$ This is another example which shows how different types of resources support one another. Here, the inclusion of resources serves to stabilize social relations and strengthens power relations which, in turn, affect the exploitation of other resource types. 
same problems, have similar day-to-day experiences and develop a mutual understanding. In an intercultural context, non-human artifacts -- such as technologies -- and existing norms and rules are particularly important to support the interaction between people in achieving common goals. Material and non-material resources also shape the course of action.

Otherwise messages could easily be misinterpreted by other actors and technologies used in a different fashion. According to this view, a regional industry cluster can be viewed as a temporarily stabilized set of social relations and accepted material and non-material resources.

Since the coherence of a regional industry configuration and its ability to work are dependent on the day-to-day interactions of its actors, distance and visibility are of great importance (e.g. Crang 1994; Depner and Bathelt 2003). Geographical proximity enables the installation of control regimes which support interaction between the firms through a multitude of micro-practices and technologies. Ongoing interaction also provides important feedback about the actions of a firm in relation to those of others. Of course, this can be accomplished relatively easily within a small territory or cluster context. The question which arises from this, however, is how social relations can be maintained if the actors do not have regular contact with one another due to a large distance between them. As demonstrated above, it is not an easy task to exercise power over distance (Murdoch 1995; Allen 1997). This requires the introduction of effective technologies and routines, which do not depend upon proximity, enabling, for instance, the decision-makers of a firm to check the outcomes of their orders which occur in different branches and places of that firm. As emphasized by Dicken, Kelly, Olds and Yeung (2001: 104), "[t]he ability of actors to reach across space and act at a distance ultimately depends upon entraining other actors and the necessary material objects, codes, procedural frameworks and so on that are required to effect the activation of power."

This is, of course, an important issue in the relationship between headquarter locations and their foreign branches. A motivation behind the establishment of international production networks is their capacity to integrate foreign actors and exercise power over distance. Due to problems which are related to cultural difference, however, interpretations could be quite heterogeneous and knowledge transfers between actors may be slowed down. In an intercultural context, network builders and boundary spanners are thus quite decisive because they are able to enroll others into networks and have the potential to communicate between the people involved. They can provide an understanding of heterogeneous habits and attitudes (Coe and Bunnell 2003; Smith 2003; Clark and Thrift 2003). These are people who have experienced different cultural contexts and, from this, are able to understand the different 
expectations and patterns of behavior and to clarify them between the actors. Overall, global executive travelling, internet 'thinking studios' and mobile, transnational 'epistemic communities' of business people have given rise to new geographies of circulation which are characterized by coherent, stable interactions and power relations (Thrift 2000; Amin and Cohendet 2004). There is no reason to assume that the rising knowledge economy will only be a regional phenomenon (Tracey, Clark and Lawton-Smith 2002).

\subsection{Social Capital}

A substantive understanding of resources presupposes that resources have objective, inherent values and that they can be assigned to specified actors based on property rights. In the previous discussions of material resources, knowledge and power, we have already demonstrated that a substantive conceptualization can be quite problematic. In the case of social capital, it is a virtual impossibility to develop a useful substantive perspective. In contrast to material resources (or physical capital), social capital cannot be attributed to individual actors or firms. Generally, it refers to the opportunities that actors draw from the quality and structure of their relations to other actors in order to pursue individual objectives (Glückler 2001; Bathelt and Glückler 2003a). Social capital is thus constituted in the very relations between the actors involved and is a result of ongoing social practices. Actors simply do not have the universal capability to exploit networks according to their own goals. They can never possess or build social capital without the active involvement of others. This concept introduces a perspective that acknowledges non-pecuniary resources as a fundamental source of power and influence and integrates these resources into a framework of multiple forms of capital (Portes 1998).

Social capital can be conceptualized at the micro and macro level. At the macro level, formal institutions, such as state constitution and legal norms, make up the social capital of a society (Putnam 1993; 1995). This social capital indicates the level of impersonal trust, i.e. the trust of individuals in the solidarity and cooperation of other -- unknown -- individuals in that society. Since this concept is based on institutions which define an overall level of reliability and certainty within a society, social capital reduces transaction costs and raises social welfare. The Word Bank's 'Social Capital Initiative' and other comparative studies suggest that a positive correlation exists between the level of social capital in a society and its economic welfare (La Porta, Lopez-de-Silanes, Shleifer and Vishny 1997; Knack and Keefer 1997; Grootaert and van Bastelaer 2001). However, there are numerous problems associated with these approaches. First, the cause-and-effect relationship is ambiguous (Knack 1999): 
does economic welfare stimulate trust or does trust generate welfare? Second, the methodology is based on aggregates of self-evaluations of individuals about their perceived trust into the overall level of cooperation in a society. Since social capital has been defined here as a resource which develops from relations between actors, it is questionable whether samples of unconnected individuals can yield any insights into the quality of social capital. Third, this methodology identifies mean levels of trust in a society which do not allow for conclusions about the unequal distribution of social capital. This procedure causes particular problems in a spatial perspective, since it neglects variations in the access to social capital within and between firms, as well as regional industry contexts or clusters. A macro-level conception does not enable context-specific, spatially-sensitive analyses and is therefore not suitable when treating social capital as a resource of firms.

At the micro level, social capital can be conceptualized as personal trust which exists in a particular community or social network. Coleman (1988) -- one of the founders of the concept (see, also, Bourdieu 1986) -- defines social capital as an accumulated history in the form of social structure which can be employed by individuals to achieve their own goals. In this perspective, resources are always built collectively, while returns can be attributed to specific individuals. Any attempt to conceptualize social capital as a private good is deemed to fail because the concept addresses social interaction rather than individual resource endowments (Putnam 1995). If we view firms from this perspective, they can no longer be viewed as isolated actors. Instead, they are integral elements of a wider structure of social relations with customers, suppliers, state agencies and lobby groups (Grabher 1993b; Podolny and Page 1998). Social capital provides a number of advantages -- or externalities -- to the members of a network. First, it enables the formation of mutual expectations and responsibilities which can be viewed as some form of credit to be claimed in the future. Second, firms have access to additional information flows within their respective networks. Third, social capital supports the formation of joint values and norms based on identity and repeated interaction. These institutions are important because they enable interaction to take place in a coherent fashion and encourage the formation of reasonable expectations within the network (Hodgson 2003). As a consequence, opportunistic behavior becomes less likely and transactions get more efficient (Coleman 1988; Collier 1998).

The formation and impact of social capital varies according to the structure of social relations. In the view of Coleman (1988), it results from the relative closure of social systems. Only if the set of relations between agents is sufficiently closed -- or redundant (Grabher 1994) -- can shared institutions be built, monitored and sanctioned. Since actors in a closed network 
are linked to many of the other actors, information, opinions and knowledge circulate widely within that network and contribute to the development of mutual trust. At the same time, however, such networks can also be quite problematic. First, internal cohesion has negative consequences for non-members since they remain excluded from information flows. Second, closed networks generate opportunities for free-riding. This occurs if individuals claim group resources which they can do simply by being members, without sharing their own resources with the group (Portes and Sensenbrenner 1993; Portes 1998). Third, closed networks can cause technological lock-in and stagnate as a consequence if important external information is missed (Kern 1996; Clark and Tracey 2004). Therefore, it is important to distinguish internal bonding relations from external bridging relations ${ }^{11}$ and integrate them into a balanced network of internal and external ties. Networks can only maintain openness for external markets and innovations, which are a prerequisite for longer-term competitiveness, if they are systematically linked to other networks.

In spatial perspective, care should be exercised when attributing social capital a priori to local or regional scales. Institutional structures and economic practices define the spatiality of social capital and embedded relations (e.g. Glückler 2001) and not space per se. There are, of course, institutions and organizations which support the formation of social capital at a national level (Putnam 1995; Grootaert and van Bastelaer 2001). Further, studies have shown that social capital can also develop at the regional level (Putnam 1993). Whether social capital is constituted locally, regionally, nationally or whether it cuts across geographical scales depends, however, on the actual patterns of interaction, as well as those institutions which enable and constrain economic action. A micro-level conception thus supports a more detailed analysis of social capital and is helpful in explaining spatial variations in localized production configurations. Regional industry clusters, for instance, can generate high levels of social capital between firms based on shared institutional frameworks and repeated face-to-face interaction (Amin 1999). If, however, social networks become too close and exclusive, the risk of neglecting external relations may rise. This could have a negative impact on resource

${ }^{11}$ The theory of structural holes defines social capital in a different way, i.e. as a set of opportunities which derive from bridging relations (Burt 1992; 1997). It suggests that information and control advantages result for those agents who bridge otherwise unconnected networks. These agents are expected to take control of the exchange relations between the networks. In this conceptualization, social capital is not attributed to the overall network of social relations but to individual brokers who are capable of establishing bridging relations. Since brokerage fosters strategies of exploitation and opportunism, open networks face more difficulties in the formation and reproduction of joint values and norms. 
availability and innovation capacity in the long run (Florida, Cushing and Gates 2002; Bathelt, Malmberg and Maskell 2004). Hence, social capital can also have negative effects (Carroll and Stanfield 2003).

In sum, the overall impact of social capital depends on the combination and integration of bonding and bridging relations within and across localized networks. In the context of global production and trade networks, executives are increasingly confronted with the uncertainty of establishing good access to and finding appropriate partners and clients in new market regions. In knowledge-intensive business services, social capital plays a decisive role when firms enter international markets. This is due to the fact that foreign competitors face considerable problems in overcoming the local clients' uncertainties (Glückler 2003). Networks between firms and individuals in firms are, however, often international in character. The type of social capital used and maintained by these business services can by no means be reduced to the regional level. Otherwise, these firms could not be successful in international markets.

A relational perspective that extends beyond the individual actor and considers the context of economic interaction is necessary in understanding the formation of social capital. Individual agents can only use social capital if mutual interdependence and interactions with others exist. This corresponds with the concept of power discussed before. All actors involved create these resources and mutually influence both the extent and distribution of the resulting returns.

\section{Conclusions: Consequences of a Relational Perspective of Resources}

The arguments presented in this paper emphasize the relational quality of resources, particularly those which have become increasingly important in the technology- and knowledge-intensive economy. We have systematically explored the shortcomings of conventional substantive understandings of resources and shown how these can be overcome by employing a relational perspective (table 1). Our arguments further provide evidence that there is a qualitative difference between the resource types investigated, i.e. between material resources and knowledge on the one hand and power and social capital on the other. This can be shown by distinguishing two levels of relationality.

Level 1 relationality. This type of relationality refers to the fact that the generation and use of resources systematically depends on the structure of social relations and institutional conditions which affect the course of economic transactions, the framework for interpretations and the choice of strategies. Level 1 relationality establishes a particular context for economic 
action and interaction which can be applied to all resources types. This context determines which resources are interpreted and used for which purpose.

Level 2 relationality. This level of relationality refers to the individual-versus-collective character of resources and becomes apparent if we distinguish between ownership of resources and ownership of returns. As opposed to material resources and knowledge which can be classified as private goods (Antonelli 2003), power and social capital are collective resources which cannot be possessed and controlled by individuals. The resources themselves cannot be attributed to the general capabilities of single agents, even though they might earn a private return from them. Instead, power and social capital are collective capacities which make the individual dependent on the overall set of related actors.

If we accept the above arguments treating resources as socially-constructed, relational entities, the question remains as to which advantages this view has in empirical studies over a conventional understanding of resources. One important advantage of the relational conceptualization presented in this paper is that it helps us avoid treating power and social capital as if they were private resources which can be attributed to individuals. Although the geography of the firm is mainly focused on measuring and explaining individual returns from resource use, those resources are constructed in a relational manner as shown in this paper and thus should be understood within their overall context of economic interaction. We argue that there are four primary advantages in applying a relational view to understand the generation and use of resources and their outcomes.

(1) Contingency of resources. A relational view of resources acknowledges that economic interaction takes place within a particular social context. Depending on this context, differences exist in the generation and exploitation of resources. As a consequence, there are no universal best practices in how to use a specific resource. In contrast, the social and institutional conditions of economic life generate differences in how agents evaluate, interpret and incorporate resources. This leads to heterogeneity and contingency in innovation and growth paths, as well as firm strategies.

(2) Collective use of resources. A relational perspective also corresponds with the view that the economy is increasingly structured by processes of learning, imitation, creation, organization and bargaining which are collective in character. Advanced economies are characterized by a deepening of the social division of labor in production and research. This is a result of the growing complexity in economic structures and processes and their systematic reflexivity. In applying a relational view, we are able to understand the processes through which resources are shaped collectively and how this affects their value. 
(3) Spatial perspective of relational resources. A relational view has further consequences for understanding economic structures in spatial perspective. Since informal institutions and structures of social relations can vary between places and regions, a perspective which emphasizes the social construction of resources enables us to understand differences in the generation and use of them, even at a small scale. Such differences can occur despite the existence of similar factor conditions and prices. This does not, however, limit our understanding of resources to the local level. Collective learning processes and knowledge generation are increasingly embedded into wider international networks of social relations. Processes, such as the exchange of implicit knowledge and the control of complex configurations of production, can be organized quite efficiently within a local or regional context -- due to the advantages of sharing the same interpretative schemes and engaging in face-to-face communication -- but they are not limited to that context. It is necessary for economic actors to acquire resources over large distances from different regional and national environments in order to get access to new markets and exchange information about technological innovation. We argue in this paper that ownership of and control over resources are by no means sufficient to organize their use and exploitation efficiently at an interregional and international level. To understand the mechanisms which enable international production configurations, we need to view power as social practice and also analyze the role of technologies in establishing stable social relations.

(4) Mutual interdependencies between resources. Finally, the relational view of resources presented in this paper enables us to understand how resources affect one another in such a way that positive returns from one resource type can be transferred to generate further positive returns from another. New combinations of material resources, for instance, which lead to product innovation also increase the knowledge about particular technologies and markets. Through this, additional innovations are likely generated and existing power networks shaped and new ones created. This links up with conceptions put forward by Coleman (1988) and Bourdieu (1986) who claim that certain forms of capital may be used to compensate for or develop other forms of capital. ${ }^{12}$ The development and use of existing resources may contribute to the improvement and re-contextualization of other resources. Resources do not serve a pre-determined purpose but are socially constructed and can be

\footnotetext{
12 While Coleman (1988) argues that social capital essentially eases the creation of human capital, Bourdieu (1986) argues that capital can be converted from one form into another. He examines particularly the convertibility from economic capital into social and cultural capital.
} 
employed in different ways. The contextuality of resources and mutual interdependencies between them indicate the profound contingency and relationality of resources and technological trajectories.

The above discussion clearly shows that a relational approach in economic geography does not just focus on the analysis of economic interaction but also takes into account the role of physical infrastructures and different types of resources. We argue that a relational conception is more appropriate than a conventional, substantive conception to understand the heterogeneous character of resources and the multiplicity of applications and strategies associated with their exploitation. As a consequence, care should be exercised in portraying resources in a mechanistic way as if their final application and use value were pre-determined.

\section{Acknowledgements}

Earlier versions of this paper were presented at the 54th Biannual Meeting of the Association of German Geographers in Bern (see, also, Glückler and Bathelt 2003) and the 100th Annual Meeting of the Association of American Geographers in Philadelphia. We are particularly indebted to Gordon Clark, Patricia McCurry, Clare Wiseman as well as to two anonymous reviewers and Nigel Thrift for their suggestions and advice. Parts of this research were funded through the Deutsche Forschungsgemeinschaft (German Science Foundation).

\section{References}

Allen, J. (1997): Economies of power and space. In Lee, R. and Wills, J. (eds): Geographies of Economies. London: Arnold, 59-70.

Allen, J. (2004): The whereabouts of power: politics, government and space. Geografiska Annaler 86 B: 19-32.

Amin, A. (1999): An institutionalist perspective on regional economic development. International Journal of Urban and Regional Research 23: 365-378.

Amin, A. (2002): Moving on: institutionalism in economic geography. Environment and Planning A 33: 1237-42.

Amin, A. (2004): Regions unbound: towards a new politics of place. Geografiska Annaler 86 B: $33-44$.

Amin, A. and Cohendet, P. (2004): Architectures of Knowledge: Firms, Capabilities, and Communities. Oxford, New York: Oxford University Press. 
Antonelli, C. (2003): Knowledge complementarity and fungeability: implications for regional strategy. Regional Studies 37: 595-606.

Arrow, K. (1962): Economic welfare and the allocation of resources for invention. In Nelson, R. (ed.): The Rate and Direction of Inventive Activity: Economic and Social Factors. Princeton (NJ): Princeton University Press, 609-625.

Asheim, B. (1999): Interactive learning and localised knowledge in globalising learning economies. GeoJournal 49: 345-352.

Bathelt, H. (2002): The re-emergence of a media industry cluster in Leipzig. European Planning Studies 10: 583-611.

Bathelt, H. (2003): Geographies of production: growth regimes in spatial perspective 1 -innovation, institutions and social systems. Progress in Human Geography 27: 763-778.

Bathelt, H. and Glückler, J. (2003a): Wirtschaftsgeographie. Ökonomische Beziehungen in räumlicher Perspektive (Economic Geography. Economic Relations in Spatial Perspective). 2nd ed. Stuttgart: UTB -- Ulmer.

Bathelt, H. and Glückler, J. (2003b): Toward a relational economic geography. Journal of Economic Geography 3: 117-144.

Bathelt, H., Malmberg, A. and Maskell, P. (2004): Clusters and knowledge: local buzz, global pipelines and the process of knowledge creation. Progress in Human Geography 28: 31 56.

Bathelt, H. and Taylor, M. (2002): Clusters, power and place: inequality and local growth in time-space. Geografiska Annaler 84 B: 93-109.

Belussi, F. and Pilotti, L. (2002): Knowledge creation, learning and innovation in Italian industrial districts. Geografiska Annaler 84 B: 125-139.

Bengtsson, M. and Söderholm, A. (2002): Bridging distances: organizing boundary-spanning technology development projects. Regional Studies 36: 263-274.

Boekema, F., Morgan, K., Bakkers, S. and Rutten, R. (2000): Introduction to learning regions: a new issue for analysis. In Boekema, F., Morgan, K., Bakkers, S. and Rutten, R. (eds): Knowledge, Innovation and Economic Growth: The Theory and Practice of Learning Regions. Cheltenham, Northampton: Edward Elgar, 3-16.

Bourdieu, P. (1986): The forms of capital. In Richardson, J. G. (ed.): Handbook of Theory and Research for the Sociology of Education. New York: Greenwood, 241-258.

Burt, R. (1992): Structural Holes: The Social Structure of Competition. Cambridge (MA), London: Harvard University Press. 
Burt, R. (1997): The contingent value of social capital. Administrative Science Quarterly 42: 339-365.

Carroll, M. C. and Stanfield, J. R. (2003): Social capital, Karl Polanyi, and American social institutional economics. Journal of Economic Issues 37: 397-404.

Clark, G. L. and Thrift, N. (2003): FX Risk in Time and Space: Managing Dispersed Knowledge in Global Finance. SPACES 2003-05. Marburg: Faculty of Geography, Philipps-University of Marburg (URL: http://www.uni-marburg.de/geographie/spaces/, retrieved August 26, 2004).

Clark, G. L. and Tracey, P. (2004): Global Competitiveness and Innovation: An AgentCentred Perspective. Houndsmill, Basingstoke, New York: Palgrave Macmillan.

Coe, N. M. and Bunnell, T. G. (2003): 'Spatializing' knowledge communities: towards a conceptualisation of transnational innovation networks. Global Networks 3: 437-456.

Cohen, W. M. and Levinthal, D. A. (1990): Absorptive capacity: a new perspective on learning and innovation. Administrative Science Quarterly 35: 128-152.

Coleman, J. (1988): Social capital in the creation of human capital. American Journal of Sociology 94 -- Supplement: S95-S120.

Collier, P. (1998): Social Capital and Poverty. Social Capital Initiative Working Papers 4. Washington (D.C.): World Bank.

Cowling, K. and Sugden, R. (1998): The essence of the modern corporation: markets, strategic decision-making and the theory of the firm. The Manchester School 66: 59-86.

Crang, P. (1994): It's showtime: on the workplace geographies of display in a restaurant in southeast England. Environment and Planning D -- Society and Space 12: 675-704.

Depner, H. and Bathelt, H. (2003): Cluster Growth and Institutional Barriers: The Development of the Automobile Industry Cluster in Shanghai, P.R. China. SPACES 2003-09. Marburg: Faculty of Geography, Philipps-University of Marburg (URL: http://www.uni-marburg.de/geographie/spaces/, retrieved August 26, 2004).

Dicken, P. (2003): Global Shift: Reshaping the Global Economic Map in the 21st Century. 4th ed. New York, London: Guilford.

Dicken, P., Forsgren, M. and Malmberg, A. (1994): The Local embeddedness of transnational corporations. In Amin, A. and Thrift, N. (eds): Globalization, Institutions, and Regional Development in Europe. Oxford, New York: Oxford University Press, 23-45.

Dicken, P., Kelly, P. F., Olds, K. and Yeung, H. W.-c. (2001): Chains and networks, territories and scales: towards a relational framework for analysing the global economy. Global Networks 1: 89-112. 
Ettlinger, N. (2003): Cultural economic geography and a relational and microspace approach to trusts, rationalities, networks, and change in collaborative workplaces. Journal of Economic Geography 3: 145-172.

Florida, R., Cushing, R. and Gates, G. (2002): When social capital stifles innovation. Harvard Business Review 80 (8): 20.

Gertler, M. S. (1997): The invention of regional culture. In Lee, R. and Wills, J. (eds): Geographies of Economies. London, New York: Arnold, 47-58.

Gertler, M. S. (2001): Best practice? Geography, learning and the institutional limits to strong convergence. Journal of Economic Geography 1: 5-26.

Gertler, M. S. (2003): Tacit knowledge and the economic geography of context, or The undefinable tacitness of being (there). Journal of Economic Geography 3: 75-99.

Glückler, J. (2001): Zur Bedeutung von Embeddedness in der Wirtschaftsgeographie (On the significance of embeddedness in economic geography). Geographische Zeitschrift 89: 211-226.

Glückler, J. (2003): Going International Under Conditions of Uncertainty: The Economic Value of Social Practice Institutions for Entry and Survival in Foreign Consulting Markets. Paper presented at the European Science Foundation Exploratory Workshop "Topics in Economic Geography: A Dialogue between Economists and Geographers" at the Centre for Economic Performance and Centre for Economic Policy Research in London.

Glückler, J. and Bathelt, H. (2003): Zur Bedeutung von Ressourcen in der relationalen Wirtschaftsgeographie: Vom Substanzkonzept zur relationalen Perspektive (Substantive and relational conceptions of resources in relational economic geography). Zeitschrift für Wirtschaftsgeographie 47: 249-267.

Grabher, G. (1993a): The weakness of strong ties: the lock-in of regional development in the Ruhr area. In Grabher, G. (ed.): The Embedded Firm: On the Socioeconomics of Industrial Networks. London, New York: Routledge, 255-277.

Grabher, G. (1993b): Rediscovering the social in the economics of interfirm relations. In Grabher, G. (ed.): The Embedded Firm: On the Socioeconomics of Industrial Networks. London, New York: Routledge, 1-31.

Grabher, G. (1994): Lob der Verschwendung. Redundanz in der Regionalentwicklung: Ein sozioökonomisches Plädoyer (Redundancy in Regional Development: A Socioeconomic Argument). Berlin: Edition Sigma -- Bohn. 
Grabher, G. (2002): Cool projects, boring institutions: temporary collaboration in social context. Regional Studies 36: 205-214.

Granovetter, M. (1985): Economic action and economic structure: the problem of embeddedness. American Journal of Sociology 91: 481-510.

Granovetter, M. (1992): Economic institutions as social constructions: a framework for analysis. Acta Sociologica 35: 3-11.

Grootaert, C. and van Bastelaer, T. (2001): Understanding and Measuring Social Capital: A Synthesis of Findings and Recommendations from the Social Capital Initiative. Social Capital Initiative Working Papers 24. Washington (D.C.): World Bank.

Hellmer, F., Friese, C., Kollros, H. and Krumbein, W. (1999): Mythos Netzwerke: Regionale Innovationsprozesse zwischen Kontinuität und Wandel (The Network Myth and Regional Innovation Processes). Berlin: Edition Sigma -- Bohn.

Hodgson, G. M. (1998): The approach of institutional economics. Journal of Economic Literature 36: 166-192.

Hodgson, G. M. (2003): The hidden persuaders: institutions and individuals in economic theory. Cambridge Journal of Economics 27: 159-175.

Johnson, B., Lorenz, E. and Lundvall, B.-Å. (2002): Why all this fuss about codified and tacit knowledge? Industrial and Corporate Change 11: 245-262.

Jöns, H. (2003): Von Menschen und Dingen: Konstruktivistisch-kritische Anmerkungen zum (a)symmetrischen Akteurskonzept der Akteursnetzwerktheorie (Humans and nonhumans: critical comments on the (a)symmetrical actor concept in actor-network theory). In Hasse, J. and Helbrecht, I. (eds): Menschenbilder in der Humangeographie (Human Images in Human Geography). Oldenburg: Bibliotheks- und Informationssystem, 109-142.

Kern, H. (1996): Vertrauensverlust und blindes Vertrauen: Integrationsprobleme im ökonomischen Handeln (Loss of Trust and Blind Trust: Problems of Integration in Economic Action). SOFI-Mitteilungen 24/1996: 7-14.

Knack, S. (1999): Social Capital, Growth and Poverty: A Survey of Cross-Country Evidence. Social Capital Initiative Working Papers 7. Washington (D.C.): World Bank.

Knack, S. and Keefer, P. (1997): Does social capital have an economic payoff? A crosscountry investigation. The Quarterly Journal of Economics 112: 1251-1288.

Koschatzky, K. (2001): Räumliche Aspekte im Innovationsprozess: Ein Beitrag zur neuen Wirtschaftsgeographie aus Sicht der regionalen Innovationsforschung (Spatial Aspects in the Innovation Process). Münster: LIT. 
Kostiainen, J. (2002): Learning and the 'ba' in the development network of an urban region. European Planning Studies 10: 613-631.

La Porta, R., Lopez-de-Silanes, F., Shleifer, A. and Vishny, R. W. (1997): Trust in large organizations. The American Economic Review 87: 333-338.

Latour, B. (1986): The powers of association. In Law, J. (ed.): Power, Action and Belief: A New Sociology of Knowledge? London: Routledge \& Kegan Paul, 264-280.

Lawson, C. and Lorenz, E. (1999): Collective learning, tacit knowledge and regional innovative capacity. Regional Studies 33: 305-317.

Leborgne, D. and Lipietz, A. (1988): New technologies, new modes of regulation: some spatial implications. Environment and Planning D -- Society and Space 6: 263-280.

Lee, Jong Ho (2001): Geographies of learning and proximity reconsidered: a relational/organizational perspective. Journal of the Korean Geographical Society 36: 539-560.

Lee, R. (2002): 'Nice maps, shame about the theory'? Thinking geographically about the economic. Progress in Human Geography 26: 333-355.

Lowey, S. (1999): Organisation und regionale Wirkungen von Unternehmenskooperationen: Eine empirische Untersuchung im Maschinenbau Unter- und Mittelfrankens (Organization and Regional Impact of Inter-firm Co-operation: An Investigation of the Machinery Industry in Lower/Middle Frankonia, Germany). Wirtschaftsgeographie 16. Münster, Hamburg: LIT.

Lundvall, B.-Å. and Johnson, B. (1994): The learning economy. Journal of Industry Studies 1: 23-42.

Mahoney, J. and Pandian, J. R. (1992): The resource-based view within the conversation of strategic management. Strategic Management Journal 13: 363-380.

Malecki, E. J. (2000): Knowledge and regional competitiveness. Erdkunde 54: 334-351.

Malmberg, A. and Maskell, P. (2002): The elusive concept of localization economies: towards a knowledge-based theory of spatial clustering: Environment and Planning A 34: 429449.

Martin, R. and Sunley, P. (1998): Slow convergence? The new endogenous growth theory and regional development. Economic Geography 74: 201-227.

Maskell, P. (2001a): The firm in economic geography. Economic Geography 77: 329-344.

Maskell, P. (2001b): Towards a knowledge-based theory of the geographical cluster. Industrial and Corporate Change 10: 921-943. 
Maskell, P. and Malmberg, A. (1999): The competitiveness of firms and regions: 'ubiquitification' and the importance of localized learning. European Urban and Regional Studies 6: 9-25.

Massey, D. (2004): Geographies of responsibility. Geografiska Annaler 86 B: 5-18.

Murdoch, J. (1995): Actor-networks and the evolution of economic forms: combining description and explanation in theories of regulation, flexible specialization, and networks. Environment and Planning A 27: 731-757.

Murphy, J. T. (2003): Social space and industrial development in East Africa: deconstructing the logics of industry networks in Mwanza, Tanzania. Journal of Economic Geography 3: 173-198.

Nelson, R. R. (1995): Evolutionary theorizing about economic change. Journal of Economic Literature 23: 48-90.

Nelson, R. R. and Winter, S. G. (1982): An Evolutionary Theory of Economic Change. Cambridge (MA): Harvard University Press.

Nonaka, I. and Takeuchi, H. (1995): The Knowledge-creating Company. New York: Oxford University Press.

Nonaka, I., Toyama, R. and Nagata, A. (2000): A firm as a knowledge-creating entity: a new perspective on the theory of the firm. Industrial and Corporate Change 9: 1-20.

Penrose, E. (1959): The Theory of the Growth of the Firm (reprint 1995). Oxford: Oxford University Press.

Penrose, E. (1997): The theory of the growth of the firm. In Foss, N. J. (ed.): Resources, Firms and Strategies: A Reader in the Resource-based Perspective. Oxford, New York: Oxford University Press, 27-39.

Peteraf, M. A. (1993): The cornerstones of competitive advantage: a resource-based view. Strategic Management Journal 14: 179-188.

Podolny, J. M. and Page, K. L. (1998): Network forms of organization. Annual Review of Sociology 24: 57-76.

Polanyi, K. (1957): The economy as instituted process. In Polanyi, K., Arensberg, C. M. and Pearson, H. W. (eds): Trade and Market in the Early Empires. Glenco: Free Press, 243270.

Polanyi, M. (1967): The Tacit Dimension. London: Routledge \& Kegan Paul.

Portes, A. (1998): Social capital: its origins and applications in modern sociology. Annual Review of Sociology 24: 1-24. 
Portes, A. and Sensenbrenner, J. (1993): Embeddedness and immigration: notes on the social determinants of economic action. American Journal of Sociology 98: 1320-1350.

Prahalad, C. and Bettis, R. (1986): The dominant logic: a new linkage between diversity and performance. Strategic Management Journal 7: 485-501.

Putnam, R. D. (1993): Making Democracy Work: Civic Traditions in Modern Italy. Princeton: Princeton University Press.

Putnam, R. D. (1995): Bowling alone: America's declining social capital. Journal of Democracy 6: 65-78.

Sayer, A. (1992): Method in Social Science. London: Routledge.

Sayer, A. (2000): Realism and Social Science. London: Sage.

Scott, J. (2001): Power. Cambridge, Oxford: Polity Press.

Smith, A. (2003): Power relations, industrial clusters, and regional transformations: panEuropean integration and outward processing in the Slovak clothing industry. Economic Geography 79: 17-40.

Storper, M. (1997): The Regional World: Territorial Development in a Global Economy. New York, London: Guilford.

Storper, M. (2003): Society, Community and Economic Development: Why Some Places Keep Developing and Others Become Blocked. Hettner-Lecture 2003 in Heidelberg.

Storper, M. and Venables, A. J. (2004): Buzz: face-to-face contact and the urban economy. Journal of Economic Geography 4: 351-370.

Strambach, S. (2004): Wissensökonomie, organisatorischer Wandel und wissensbasierte Regionalentwicklung (Knowledge economy, organizational change and knowledgebased regional development). Zeitschrift für Wirtschaftsgeographie 48: 1-18.

Taylor, M. (1995): The business enterprise, power and patterns of geographical industrialisation. In Conti, S., Malecki, E. J. and Oinas, P. (eds): The Industrial Enterprise and its Environment: Spatial Perspectives. Aldershot: Ashgate, 99-122.

Taylor, M. (2000): Industrialisation, enterprise power, and environmental change: an exploration of concepts. Environment and Planning A 28: 1035-1051.

Thrift, N. J. (1996): Spatial Formations. London: Sage.

Thrift, N. (2000): Performing cultures in the new economy. Annals of the Association of American Geographers 90: 674-692.

Tracey, P., Clark, G. L. and Lawton Smith, H. (2002): Cognition, Learning and European Regional Growth: An Agent-Centred Perspective on the 'New' Economy. School of 
Geography Working Paper 02-10. Oxford: School of Geography and the Environment, University of Oxford.

Wernerfelt, B. (1984): A resource-based view of the firm. Strategic Management Journal 5: 171-180.

Yeung, H. W.-c. (1994): Critical reviews of geographical perspectives on business organizations and the organization of production: towards a network approach. Progress in Human Geography 18: 460-490.

Yeung, H. W.-c. (1998): The socio-spatial constitution of business organizations: a geographical perspective. Organization 5: 101-128.

Yeung, H. W.-c. (2002): Towards a Relational Economic Geography: Old Wine in New Bottles? Paper presented at the 98th Annual Meeting of the Association of American Geographers in Los Angeles. 
Table 1. Substantive Versus Relational Understandings of Resources

\begin{tabular}{|c|c|c|}
\hline Resource type & Substantive understanding & Relational understanding \\
\hline Material resources & $\begin{array}{l}\text { Resources as production factors } \\
\text { characterized by pre-defined } \\
\text { input-output relationships }\end{array}$ & $\begin{array}{l}\text { Resources as bundles of possible } \\
\text { services characterized by } \\
\text { contingent returns }\end{array}$ \\
\hline Knowledge & $\begin{array}{l}\text { Knowledge as a precondition for } \\
\text { economic success characterized } \\
\text { by inherent, pre-determined } \\
\text { consequences }\end{array}$ & $\begin{array}{l}\text { Knowledge as a (frequently } \\
\text { unanticipated) result of collective } \\
\text { interpretations and } \\
\text { recombinations }\end{array}$ \\
\hline Power & $\begin{array}{l}\text { Power as the inscribed capacity } \\
\text { of an actor to dominate by means } \\
\text { of resource control }\end{array}$ & $\begin{array}{l}\text { Power as the social practice of } \\
\text { building networks and enrolling } \\
\text { other actors in joint projects }\end{array}$ \\
\hline Social capital & $\begin{array}{l}\text { Social capital as the universal } \\
\text { capability of an actor to exploit } \\
\text { networks according to her/his } \\
\text { own goals }\end{array}$ & $\begin{array}{l}\text { Social capital as the set of } \\
\text { opportunities which results from } \\
\text { the existence of social relations } \\
\text { with other actors }\end{array}$ \\
\hline
\end{tabular}


